\title{
IMPACT OF COVID-19 PANDEMIC ON TOURISM: RECOVERY PROPOSAL FOR FUTURE TOURISM
}

\author{
Santus Kumar DEB \\ University of Dhaka, Department of Tourism and Hospitality Management, Bangladesh, e-mail: santus@du.ac.bd \\ Shohel Md. NAFI" \\ Noahkhali Science and Technology University, Department of Tourism and Hospitality Management, Bangladesh, e-mail: smnafi13@gmail.com
}

Citation: Deb, S.K., \& Nafi, S.M. (2020). IMPACT OF COVID-19 PANDEMIC ON TOURISM: RECOVERY PROPOSAL FOR FUTURE TOURISM. GeoJournal of Tourism and Geosites, 33(4spl), 1486-1492. https://doi.org/10.30892/gtg.334spl06-597

\begin{abstract}
The aim of the study was to examine the consequence of the COVID-19 pandemic on tourism. Qualitative analysis was adopted, whereas data were collected from secondary sources like journals, newspapers, statistical data obtained from international to urism organizations, and websites on COVID-19 incidences in tourism. Due to the outbreak, it had a severe adverse impact on tourism and employment. Airlines have canceled flights, and hotels are almost vacant; thus, supporting tourism agencies face substantial economic losses and employ ment cuts. This study develops a framework with a recovery plan for future tourism across a slogan: putting people first and travel tomorrow.
\end{abstract}

Key words: COVID-19, tourism, travel restriction, pandemic, future tourism.

$* * * * * *$

\section{INTRODUCTION}

The World Health Organization (WHO) proclaimed on January 31, 2020, that the COVID-19 outbreak in China constituted a 'Public Health Emergency' of Global Concern (ABC News, 2020; Ying et al., 2020). COVID-19 is a novel coronavirus respiratory sickness that was first identified in Wuhan, China, in December 2019 (Brüssow, 2020; Fauci et al., 2020; Gentile and Abenavoli, 2020; Shang et al., 2020). The outbreak has spread to 210 countries and regions around the world (Worldometers, 2020). However, 210 countries and two international conveyances have been affected by the COVID-19 outbreak, wherein 32,769,408 confirmed cases and 993,542 deaths have occurred as a result (last update: September 26, 2020). The global tourism market has been growing significantly in the last few decades. In 1950, the total number of tourist arrival was only 25 million that is reached 1.5 billion in 2019 . However, the growth in the overall world tourism market has been influenced by the spread of infection diseases (Baker, 2015). Travelers can easily transmit person-to-person infections from one part of the country to another country as has been seen recently with the coronavirus. The COVID-19 global crisis has already created an economic, social, and labor market shockwave, affecting all product supply and demand. Interruption in production has now extended to global supply chain systems (ILO, 2020). All varieties of businesses, irrespective of size, are currently facing tremendous challenges. However, aviation, tourism, and hospitality industries have faced continuous challenges since the beginning of the pandemic, with significant drops in revenue and growth, as well as job losses in particular sectors following travel bans and border closure measures. It is most challenging for small and medium sized businesses to sustain themselves at present without assistance. For the uncertainty and wide range of spread of COVID-19, the United Nations World Tourism Organization (UNWTO) has suggestively reviewed their prediction for the year 2020.

The tourism and travel industry is one of the world's biggest industries, offering rich experiences to travelers and contributing to community development. Moreover, Jamal and Budke (2020) stated that "in the present globalized world, threats and challenges have amplified alongside the easiness of travel and swift movement of goods, knowledge, finance, and diseases". However, health emergencies and climate change are the two most challenging factors for the tourism industry. COVID-19 is one of the most significant new challenges to the tourism industry. A pandemic that began in the Hubei province of China has disseminated quickly, and considerable outbreaks are currently occurring in the USA, the UK, France, Spain, Italy, the Middle East, and Asia. The economic consequences could include recessions in the USA, Europe, Africa and Asia. China has already experienced the slowest growth on record with a total of USD 2.7 trillion in lost output, which is equal to the whole GDP of the U.K. (Orlik et al., 2020). Moreover, tourism destination development, planning and implementation of the systems can be performed by proper monitoring arrangements that involve the active and balanced involvement of all the related stakeholders. A stakeholder is described as "any group of people or in dividuals who can affect or are affected by" tourism activity in a particular area (Freeman, 1984). Tourism stakeholders may be classified as the tourists, business owners, government, employees, local community and suppliers. The active participation and cooperation of tourism stakeholders make this industry one of the biggest industries in the world. Tourism stakeholders' involvement and participation can strengthen the recovery process from any kind of disaster. However, the stakeholder role is essential in the overall recovery process from the COVID-19 pandemic.

\section{PURPOSE OF THE STUDY}

The tourism industry is perceived to be entering and going through an unprecedented crisis period that is already projected by recent trends. The operation of hotels, resorts, tour operators, airlines, and other tourism-related services is currently blocked. Due to the COVID-19 pandemic, the tourism sector is facing exceptional challenges. The COVID-19 outbreak has triggered both health insecurity and the economic downturn. This study develops a framework that shows the interrelationship among the different stakeholders and their role in the COVID-19 situation. This study also constructs a guideline for industry stakeholders to make decisions during the pandemic.

\section{RESEARCH METHOD AND MATERIAL}

Researchers have collected vast volumes of data all over the world; the feasibility of utilizing current data for the study is becoming more widespread (Andrews et al., 2012; Smith, 2008). When data were collected from some other sources that are published by someone

\footnotetext{
${ }^{*}$ Corresponding author
} 
else is called secondary data. The study adopted a secondary research approach based on secondary data. First, the study examined the effects of COVID-19 on the world tourism sectors. Furthermore, secondary data related to the impact of this epidemic on the tourism industry were identified and analyzed. The researchers performed the analysis by reviewing encyclopedias, journals, documents, historical records, newspaper articles, studies, UNWTO statistics, governmental data, and websites. Authentic, topical research was conducted with critical secondary materials from selected literature (Grewal et al., 2016). Only a few studies have been published that examined the consequences of COVID-19 on travel and tourism. Researchers also developed a theoretical model of the tourism recovery plan for the COVID-19 outbreak based on expert opinion, theoretical aspects and the report of UNWTO.

\section{COVID-19 AND TOURISM SCENARIOS}

International Tourism 2020 Scenarios

Last few years, the tourism industry has experienced sharp growth in the number of tourist arrival and in tourist receipts. In 2019, international tourist arrivals raised by 4 percent to reach 1.5 billion globally. For that reason, experts around the world were expected that 2020 would be another successful year for tourism. However, the COVID-19 outbreak changes the overall scenario for the industry. Bakar and Rosbi (2020) analyze the economic outcome of COVID-19 to the tourism industry and show it creates one kind of panic among consumers that lower the tourism demand. An early overview of COVID-19 has been presented by Fernandes (2020) and illustrates the countries that are greatly dependent on foreign trade are more negatively affected by the present crisis. Karim et al. (2020) describe the movement control order and its impact on Malaysia tourism and find that employees from the hospitality sector were asked to take unpaid leave, and the aviation sector minimizes the flight operations for the reason of COVID-19. However, these types of scenarios are almost the same globally at present. Korinth and Ranasinghe (2020) find that in Poland, the hotel occupancy level decreased by about 40 percent and air traffic on Poland airport fell by about $80-90$ percent by early March compared to the last year. This result indicates the early impact of COVID-19, which is more severe in later. Besides the business and service industry, community people have also suffered a lot from any disaster-affected tourism industry. Wahyuningtyas et al. (2020) provided an overview of disaster and community preparedness and showed that the community has lacked in this regard. For that reason, proper training, policy and management implication is necessary for this aspect to mitigate the impact. The following Table 1 shows the outlook for international tourist arrival in the last two years, early projection of tourist arrival in 2020 and the present condition.

Table 1. Outlook for International Tourist Arrival (Source: UNWTO, 2020a; 2020c)

\begin{tabular}{|c|c|c|c|c|c|c|}
\hline \multirow[t]{2}{*}{ Region } & \multicolumn{2}{|c|}{ Change (\%) } & \multirow{2}{*}{$\begin{array}{c}\text { Average a year }(\%) \\
2009-2019 \\
\end{array}$} & \multirow{2}{*}{$\begin{array}{c}\text { 2020 Projection } \\
\text { (issued in January) }(\%) \\
\text { from } \\
\end{array}$} & \multirow{2}{*}{$\begin{array}{c}2020 \text { (January to April) } \\
\text { (change \%) }\end{array}$} & \multirow{2}{*}{$\begin{array}{c}2020 \text { (January to June) } \\
\text { (change \%) }\end{array}$} \\
\hline & 2018 & 2019 & & & & \\
\hline World & 5.6 & 3.8 & 5.1 & 3 to 4 & -44 & -65 \\
\hline Europe & 5.8 & 3.7 & 4.6 & 3 to 4 & -44 & -66 \\
\hline Asia and Pacific & 7.3 & 4.6 & 7.1 & 5 to 6 & -51 & -72 \\
\hline American & 2.4 & 2.0 & 4.6 & 2 to 3 & -36 & -55 \\
\hline Africa & 8.5 & 4.2 & 4.4 & 3 to 5 & -35 & -57 \\
\hline Middle East & 3.0 & 7.6 & 2.7 & 4 to 6 & -40 & -57 \\
\hline
\end{tabular}

In the first six months of 2020, international tourist arrivals declined by 65 percent, where Asia and the Pacific region is the worst hit by 72 percent decline (UNWTO, 2020a; 2020c). However, outlooks for the year have repeatedly been decreased because of an outbreak and uncertainty. After the complete shutdown of most international borders in late March, tourist arrivals submerged 97 percent in April and 96 percent in May and 85 percent in August (UNWTO, 2020a). This depends on containment speed and movement restrictions and border shutdowns. The following Figure 1 shows, 2020 scenarios are based upon three potential opening dates for international boundaries.

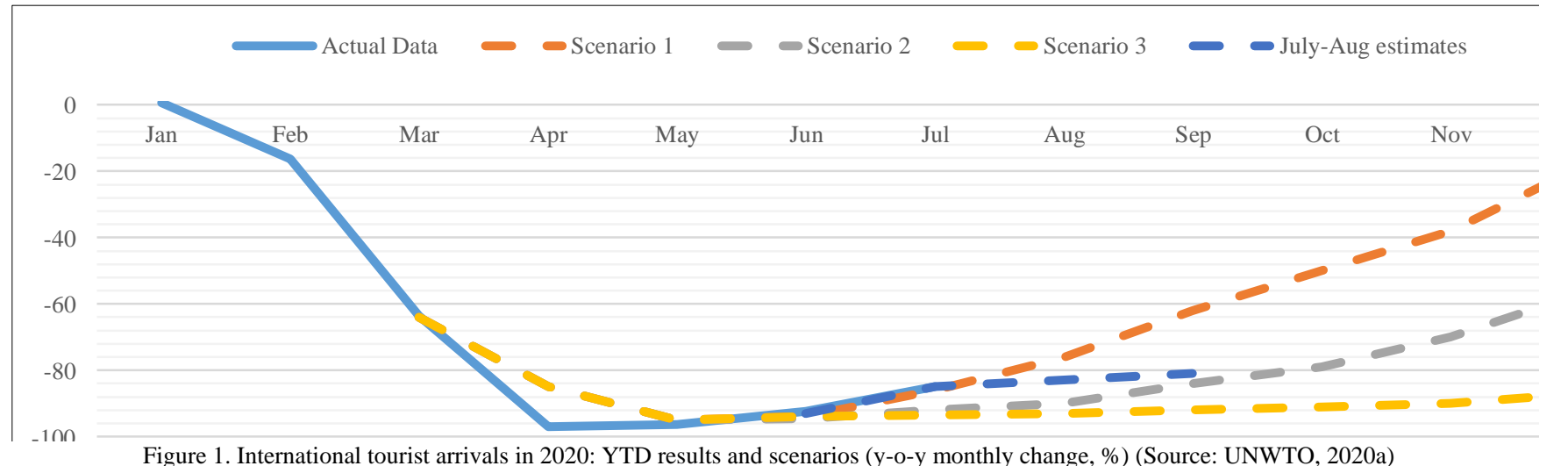

Figure 1. International tourist arrivals in 2020: YTD results and scenarios (y-o-y monthly change, \%) (Source: UNWTO, 2020a)

It will be by far the most significant decline of the historic sequence arrivals, eclipsing the $4 \%$ decrease following the global economic crisis in 2009 or the moderate $0.4 \%$ fall following the SARS outbreak in 2003. However, some studies suggested that the domestic travel market would recover faster than the international market. According to a survey conducted by about 280 participants on the impacts of the 19 outbreaks on tourism destinations, the UNWTO Panel of Experts anticipates a quicker recovery of domestic demand than foreign demand. Figure 2 shows that almost half of respondents (45\%) report a rise of domestic tourism demand in July-September 2020, with 25\% anticipating this to be achieved in October-December. More than $70 \%$ of respondents expect international demand to recover in the fourth quarter of 2020 (34\%), and mostly in 2021 (39\%).

COVID-19 Pandemic and International Tourism

Personal health and safety concerns are vital factors that tourists take into account when selecting a travel destination. Fotiadis and Huan 
(2014) stated that tourist travel choices greatly depend on the presence of any disaster that could affect their welfare and safety. Plog (2001) described how allocentric tourists search for destinations for adventure and cultural and environmental experiences.

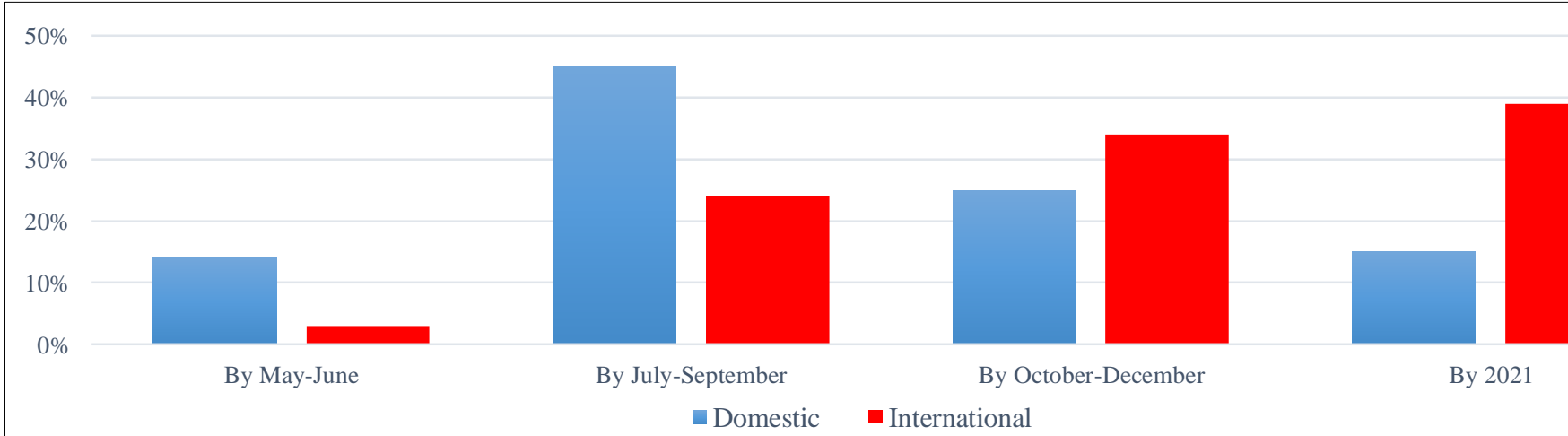

Figure 2. Domestic Demand and International Demand Recovery Projection for Tourism (Source: UNWTO, 2020f)

However, the travel and tourism industry sometimes faces natural or man-made disasters that affect the entire industry (Huan et al., 2004). The impact of these disasters may be isolated to a specific area or have a global impact, which can determine how long the effects of the disaster are felt. As the tourism industry is one of the sectors most affected by these disasters, special attention to recovery plans is needed during these events. The most recent crisis to affect the travel and tourism industry is the COVID-19 outbreak, which was first acknowledged in early January in China. It is now being treated as a pandemic, and by mid-June has affected more than eight million people globally. This situation is quite unusual that radically changes the world scenario. Within a few months, the farming of the world tourism structure changed from over-tourism (e.g., Dodds and Butler, 2019; Seraphin et al., 2018) to zero-tourism for a particular time. Only a few tourism activities are taken place all over the world in this pandemic situation, which can be denoted as zero tourism.

This time the world witnesses a situation where all the businesses are closed, airlines canceled flights, and hotels and restaurants are empty and destinations are without tourists. The global tourism industry has experienced a widespread crisis in the past time. Gössling et al., (2020) illustrate the significant crisis events in tourism between 2000 to 2015 that is shown in Figure 3. Between these periods, the global tourism industry has witnessed four short-term crisis events that are confined within a specific region. However, the Arab Spring in Egypt and Tunisia in this decade also demonstrates a major challenge for the tourism industry. In 2014 to the first half of 2016, terrorist attacks on tourists happened in Egypt and Tunisia which results in negative political consequences and remarkably decreased tourist flow (Wendt, 2019). After these events, the tourism industry has recovered quickly. Nevertheless, there are many indications and reports which suggested that the impact and repossession from the pandemic of COVID-19 would be exceptional (Gössling et al., 2020).

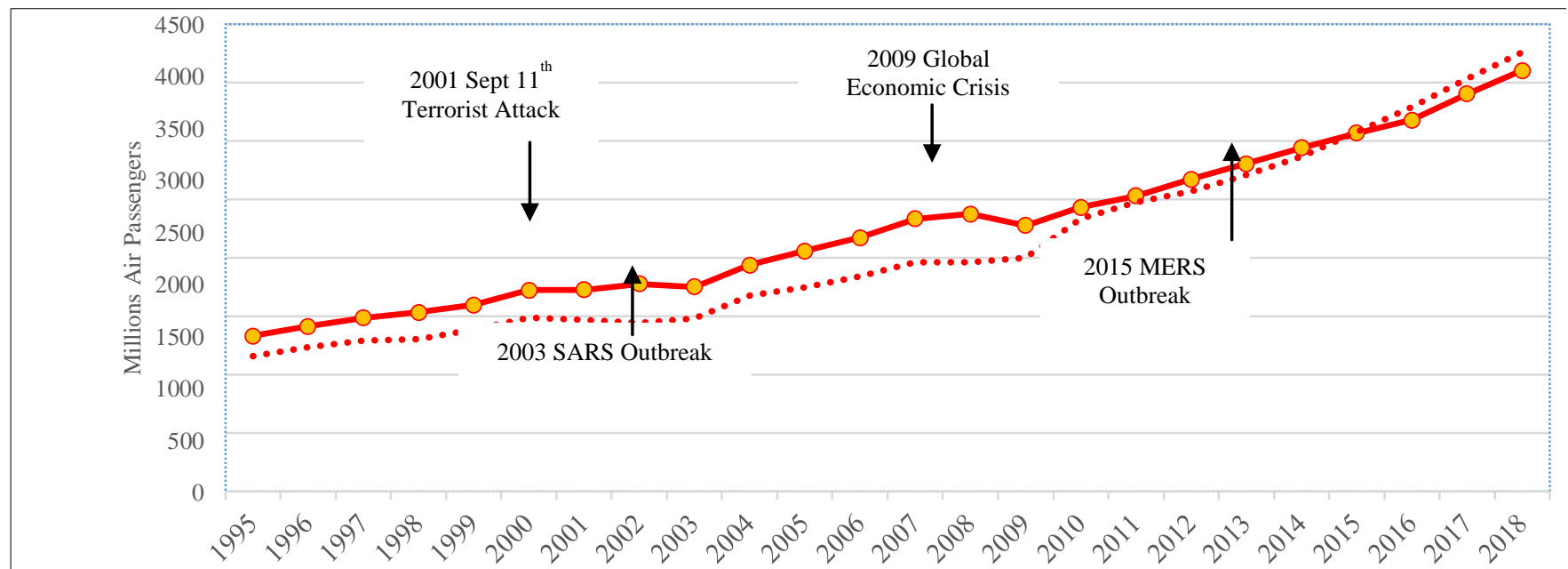

Figure 3. Effect of Crisis Events on Global Tourism (Source: World Bank, 2020̄a, 2020b)

Moreover, countries with the highest COVID-19 confirmed cases are also known as a popular tourist destination in the world. Table 2 shows the countries with the highest COVID-19 confirmed cases (data reported by the World Health Organization on May 11, 2020) and their share in the tourism industry. The top twelve affected countries account for $39 \%$ of world tourist arrival, $42 \%$ of world tourism receipts and 54\% of world tourist expenditure (UNWTO, 2020b). In terms of tourist arrival in 2018, France, Spain, the United States of America, China, Italy, Turkey, Germany and the United Kingdom are placed in the top 10 destinations and receive 498 million tourists out of 1401 million tourists that are 35.54 percent of total tourist arrival. Moreover, except Turkey, these countries were also placed in top position as the leading tourism earners list and earned US 539 billion in 2018, which is 37.15 percent of total receipts.

\section{DISCUSSION AND FINDINGS}

The global tourism industry has faced a considerable crisis due to the global COVID-19 outbreak. The actual impacts of the COVID-19 outbreak on tourism will not be apparent until after the pandemic has ended. Over the last few decades, the global travel and tourism industry has experienced continuous growth and has contributed to approximately $10 \%$ of the global GDP, creating almost 1 in 10 jobs worldwide. 
Table 2. Countries with Maximum COVID-19 Confirmed Cases and Share in Tourism; Source: UNWTO (2020b)

\begin{tabular}{|c|c|c|c|c|}
\hline $\begin{array}{c}\text { Countries with Highest } \\
\text { COVID-19 Confirmed Cases }\end{array}$ & $\begin{array}{c}\text { Share of World Tourist } \\
\text { Arrival (\%) }\end{array}$ & $\begin{array}{c}\text { Tourism Share of Exports } \\
\text { in the Country }(\%)\end{array}$ & $\begin{array}{c}\text { Share of World Tourism } \\
\text { Receipts (\%) }\end{array}$ & $\begin{array}{c}\text { Share of World Tourism } \\
\text { Expenditure }(\%)\end{array}$ \\
\hline United States & 5 & 10 & 15 & 10 \\
\hline Spain & 6 & 16 & 5 & 2 \\
\hline Russian Federation & 2 & 8 & 1 & 2 \\
\hline United Kingdom & 3 & 6 & 4 & 5 \\
\hline Italy & 4 & 8 & 3 & 2 \\
\hline Germany & 3 & 3 & 3 & 7 \\
\hline Brazil & 0 & 2 & 0 & 1 \\
\hline France & 6 & 8 & 4 & 3 \\
\hline Iran & 1 & 5 & 0 & 1 \\
\hline China & 4 & 1 & 3 & 19 \\
\hline Canada & 2 & 5 & 2 & 2 \\
\hline Total & 39 & & 42 & 54 \\
\hline
\end{tabular}

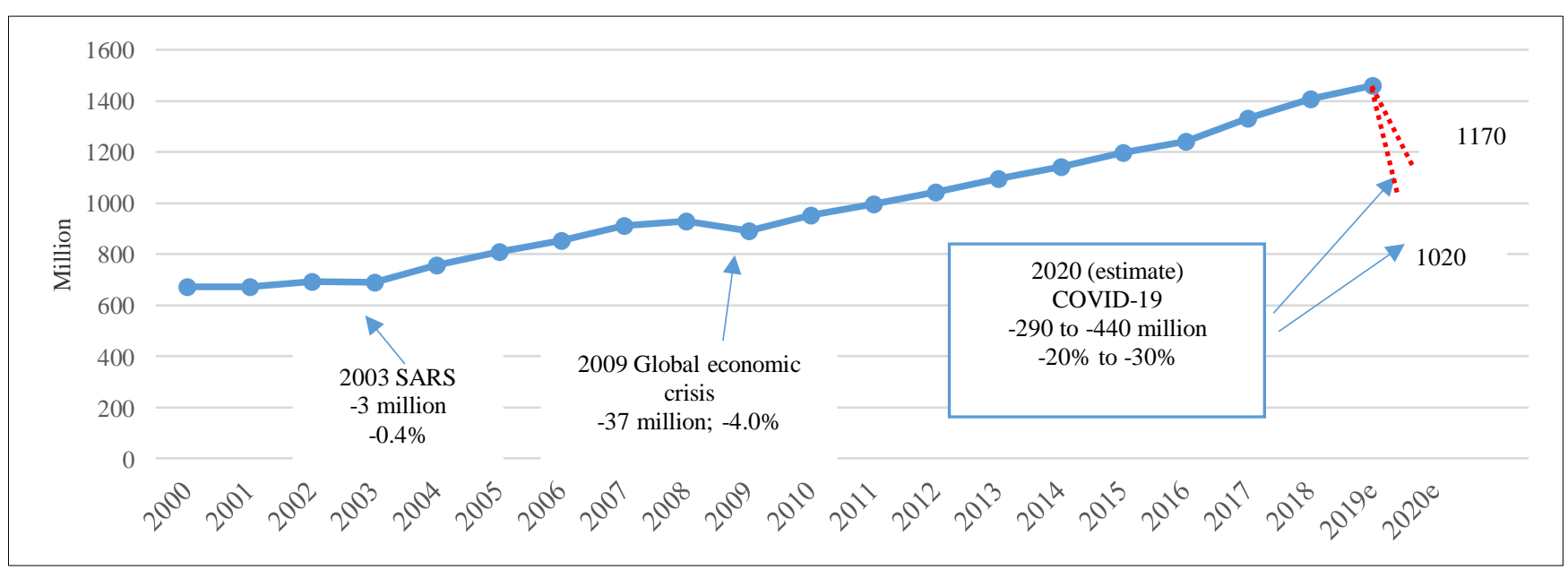

Figure 4. International Tourist Arrivals Forecasting for 2020; (Source: UNWTO, 2020e)

According to UNWTO (2020c), in 2019, the number of global tourists reached 1.5 billion, a growth of $4 \%$ over the previous year. Additionally, the WTO forecasted 3\% to 4\% growth in international tourist arrivals in 2020. The COVID-19 outbreak has caused the tourism industry to experience negative growth. According to the UNWTO (2020d), 96 percent of global travel destinations have imposed travel restrictions and close their borders completely or partially for the tourists. In Figure 4, UNWTO has earlier projected that international tourist arrivals will fall by 20-30\% in 2020 (UNWTO, 2020e). Figure 5 shows the projected impact of COVID-19 on tourism industry revenue in the current year. The decline in the world travel situation as a result of the pandemic might reduce international export revenues by a best case scenario of US\$ 910 billion and up to US\$ 1.2 trillion in the three 2020 scenarios outlined in this report (Databd.co, 2020). Visitors to destinations may decrease, depending on the speed of normalization and the reopening of national frontiers, from US\$1.480 billion for 2019 to a range of US\$ 310-570 billion by 2020. This represents a drop in nominal terms of 62 to 79 percent, much deeper than the nominal decline in 2009 ( -5 percent real) during the global economic crisis.

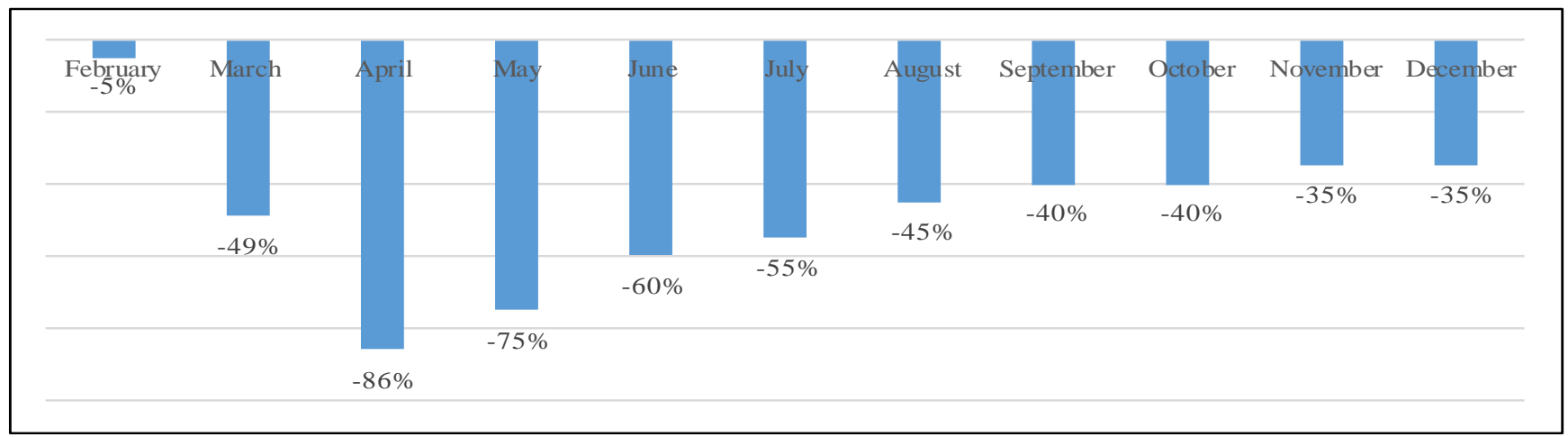

Figure 5. Projected Effect of COVID-19 on Tourism Industry Revenue in 2020 (Source: Databd.co, 2020)

The World Travel and Tourism Council (WTTC) has reported that the pandemic of COVID-19 places approximately 50 million jobs worldwide in the travel and tourism sector at threat (World Economic Forum, 2020). Moreover, the World Travel \& Tourism Council (WTTC), 100.8 million is presently at risk in the tourism sector with 1 million jobs being lost every day (WTTC, 2020). Figure 6 shows the estimated job losses in the tourism sector by world regions. However, Asia is projected to be the worst affected area in the world. Approximately 30 million people in Asia are projected to lose their jobs, followed by seven million in Europe, five million in the USA, and the rest of the world (World Economic Forum, 2020). 
COVID-19 change the overall business situation in all over the world. Tourists number are falling dramatically, revenue is shrinking and people lose their job- it is the real depiction of the tourism industry. The uncertain length of the pandemic makes the situation more complicated. At present, it is essential to address the pandemic situation and to sustain in the market. However, the tourism industry and related stakeholders must focus on the after pandemic situation to revive the business which will call the "new normal" condition.

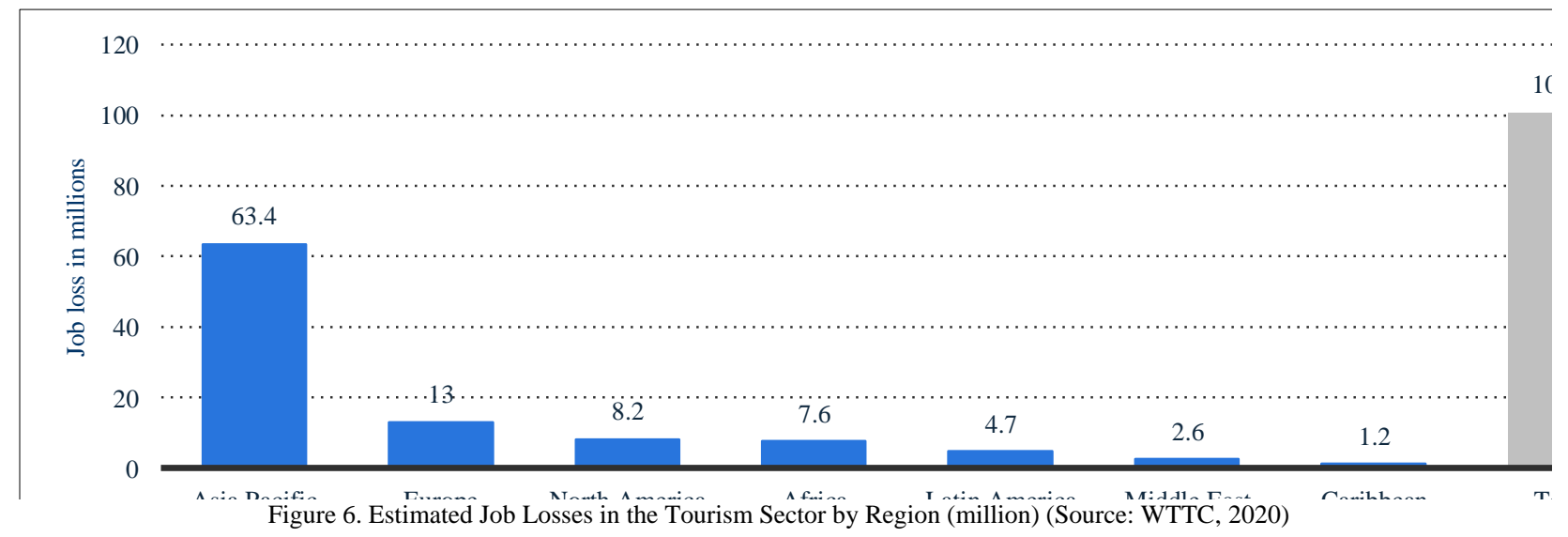

Tourism Industry after the Pandemic

The tourism industry is now undergoing remarkable pressure in all over the world. For that reason, it is inevitable to figure out the possible scenario after the Covid-19 crisis.

I. Low incidence of Current Pandemic: If the current pandemic is over within six months, the impact could be low in the tourism industry. In this situation, countries all over the world would lift travel restrictions for international tourists. The world economy will stop failing and retrieve from the recession, but small tourism enterprises will need help from the government. Tourist's possible fear and cautions caused by the pandemic will be relaxed. People will be back in regular life easily; only a few people will be affected by their jobs and livelihood, but they will recover it within a short time. However, all the travel and tourism-related business and activities are being closed from the last few months. In this low incidence situation, both the private and public sector businesses will recover their losses within a few months. For that reason, tourism enterprises will offer attractive packages to potential tourists.

II. Medium Incidence of Current Pandemic: If the pandemic will continue more than six months and end within one year, the overall situation will be severe for some of the cases. Some small and medium tourism enterprises will face some sort of problem to run their business because of lockdown. However, short of working capital long time lockdown will force some businesses to wind up from the market. This type of situation will force the business to reduce the labor forces. Simultaneously, the living standard and earning level of people will decrease, which will poorly impact future tourism growth. As a result, people will reduce their budget for travel and recreation. Moreover, in this situation, governments of different countries would restrict their border for foreign tourists.

III. High Incidence of Current Pandemic: This is the most challenging situation of the current pandemic. If the pandemic continues more than one year that will severely affect the overall psychological, economic and sociological structure of the society. Despite the size, survival will be the prime objective for businesses. Severe types of unemployment problem will arise in all over the world. The tourism industry will face negative growth for the next few years. However, many tourism and travel business have not weathered the economic pressure and have disappeared. At this stage, long-term government support is necessary to revive the tourism activities.

The following table shows the projected period of the current pandemic along with the tourism stakeholders' role in this situation.

Table 3. Projected Period of Current Pandemic and Tourism Stakeholders' Role

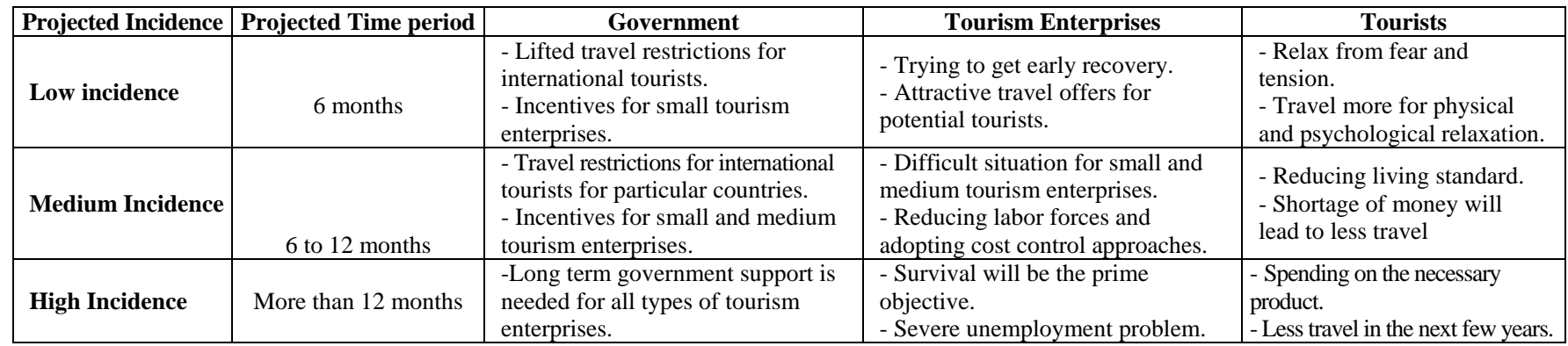

\section{PROPOSALS TO MITIGATE THE IMPACT OF THE CRISIS}

Countries, most popular tourist destinations, will need to evaluate and calculate the effects of the COVID-19 outbreak on tourism in terms of economic and non-economic value. The tourism industry is in danger of experiencing strong economic downturns (Pastor, 2020). According to Novelli et al. (2018), perception should also be compared with other structurally organized institutional situations and global influences, i.e., climate change, which increases the vulnerability of less affluent areas that are already stressed, in order to improve community resilience following future epidemics (e.g., Ebola, and Zika virus).

The authors have developed a theoretical model of the effects of the COVID-19 pandemic on the tourism industry to understand its adverse impact on tourism better. Figure 7 shows that COVID-19 has had an adverse impact on the tourism industry. This figure shows the interrelationship among the different stakeholders and how they are affected by the COVID-19. In this situation, tourism destination organizations (DMO) and government agencies must support the related stakeholders. However, all the players in this interrelated process are important for this industry. This figure shows that both national and international tourists traveling for leisure, business, and other 
purposes canceled hotel reservations and flight tickets. The worldwide COVID-19 outbreak triggered fear among potential tourists, encouraging them to stay home and avoid traveling for leisure. From the beginning of the COVID-19 pandemic, most tour-related support agencies faced substantial economic losses and workers lost their jobs. This is easily assumed that standards of living in tourism-focused communities will be decreased as the unemployment rate continues to rise. However, it is essential to calculate the impact of COVID-19 in the tourism industry which is mainly undertaken by the market researchers and experts of tourism. Statistical data analysis, secondary data analysis and different types of published reports will help regarding this issue. This theoretical model presented in this study will help future researchers to conduct their research in this field.

This review identifies that the emergence of the COVID-19 pandemic has severely affected the tourism industry all over the world. Inbound, outbound and domestic tourist activities have been suspended since mid-June. Tourism industry stakeholders are suffering significant losses as the amount of all types of tourism activities are decreasing. In this situation, pandemics must be carefully managed in a way that will revitalize the tourism industry; mentioned policies are needed to implication:

- Responsible Tourism to revive live and livelihood by maintaining health guidelines, wearing the mask during, upholding social distance, tourists must protect themselves. The tourism business must consider all sorts of guidelines when reopening the business. That will protect tourists, businesses, society, and the world for a better future with a slogan Putting People First.

- Throughout the COVID-19 pandemic, focus on urban tourism development for the continuous development of tourism.

- During and after the pandemic, government incentive programs must be available or loan repayment relaxation for small and medium businesses, including cash support to the tourism industry employees. This type of support must have a social objective by endorsing support for the constant activity of businesses and, therefore, for workers' jobs. As tourism is a labor intensive industry, both formal and informal employees, must be addressed.

- Electronic and print media should take a positive approach to support the tourism industry during and after the COVID-19 pandemic.

- Public, Private and Community Partnership (PPCP) is necessary for the tourism sector to overcome the losses. The policymaker overlooks community people most of the time but their inclusion is essential in any type of incentive package. In many destinations, the livelihoods of community people depend on tourism activities.

- Studies are needed that focus on potential direct and indirect impacts on local communities or cities that depend on tourism.

- After the pandemic, the next few years business should take a cost-cutting approach like video conferencing, virtual tourism conferences, virtual meetings, and virtual tourism fairs. Business and researchers need to monitor tourist behavior, which may be changed due to social and economic changes of COVID-19.

- World tourism organization (UNWTO) may call international organizations, donor agencies, and political support for quick recovery from the pandemic and also make broader actions and recovery plans to revive the tourism industry and economy.

- In the post-viral world, people might be allowed to travel with antibodies against COVID-19 freely with some sort of health assurance and offer discounts and packages on airlines and hotels.

- WTTC will be beneficial for the tourism industry, providing effective guidance with action plans for the response to the global pandemic for tourism organizations (McKercher and Chon, 2004; Sönmez et al., 2019).

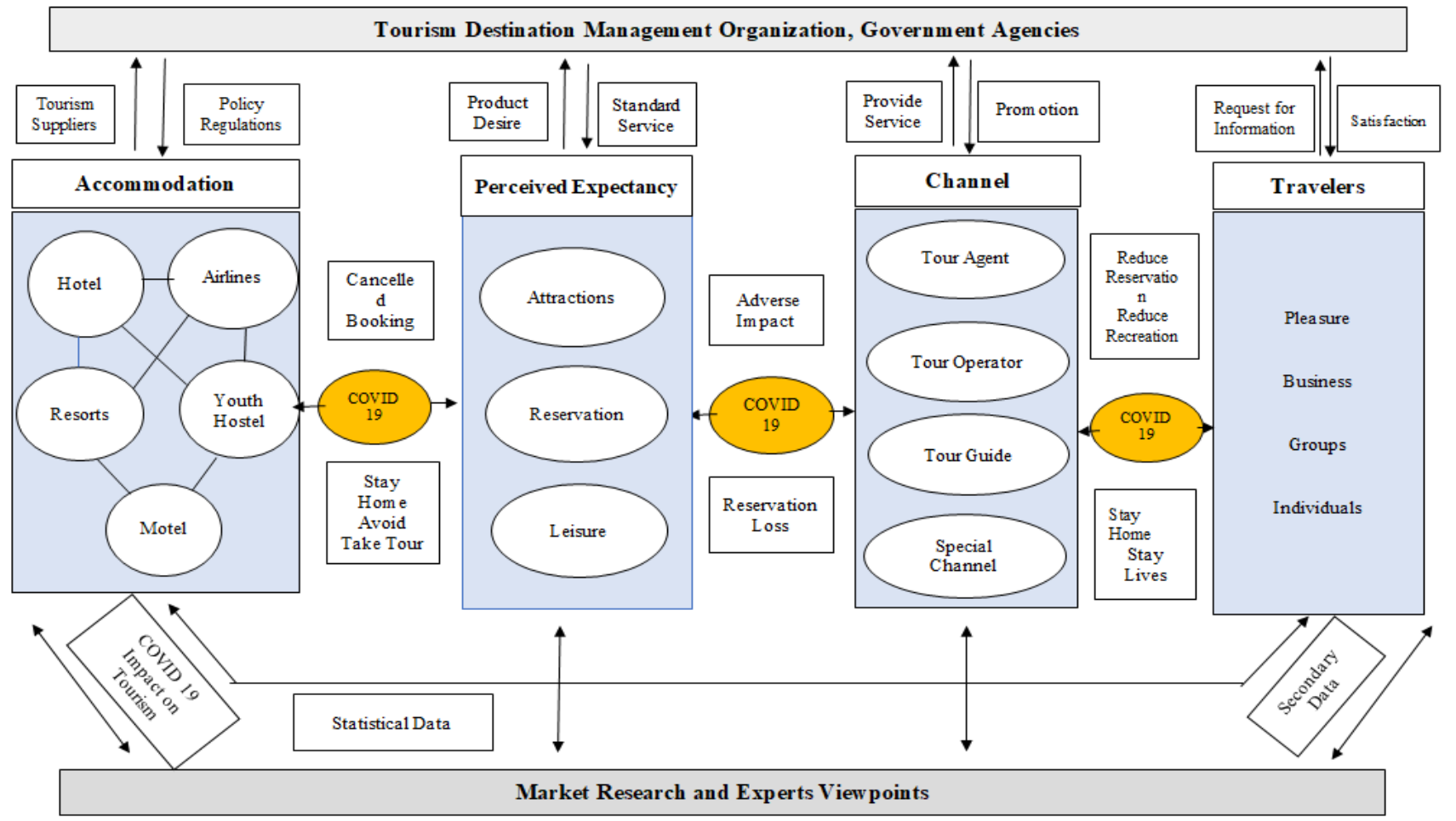

Figure 7. Covid-19 Impact on Tourism: Theoretical Recovery Model (TRM) (Source: Developed by Authors)

\section{CONCLUSION}

The global COVID-19 pandemic has already become an economic, social, and labor crisis, affecting the supply and demand of all products. The effect of COVID-19 on the global tourism industry is likely to be more damaging than any other previous event. This study presents the early impacts of the COVID-19 pandemic on the tourism industry. The impacts will likely be long-lasting and be felt for the next two to three years. With the enormity of the COVID-19 outbreak, it is not essential to come back business as a traditional way when 
the pandemic ended, rather than it can be a scope to reevaluate a transformation of the overall tourism system for the sustainability

(Gössling et al., 2020). Moreover, after the pandemic, it is crucial to return the business in a normal condition.

This situation would give an opportunity to think about the current business structure of the tourism industry which may need to reform to address crisis moment, to protect business and to protect jobs. That means that a comprehensive plan is required to revive the tourism industry. Future studies should investigate the consequences of the COVID-19 outbreak on inbound and outbound tourism, tourist behavior, employment, and the overall growth rate in the tourism industry.

\section{REFERENCES}

Andrews, L., Higgins, A., Andrews, M.W., \& Lalor, J.G. (2012). Classic grounded theory to analyse secondary data: Reality and reflections. The Grounded Theory Review, 11(1), 12-26.

Bakar, N.A., \& Rosbi, S. (2020). Effect of Coronavirus disease (COVID-19) to tourism industry. International Journal of Advanced Engineering Research and Science, 7(4), 189-193. https://doi.org/10.22161/ijaers.74.23

Baker, D.M.A. (2015). Tourism and the health effects of infectious diseases: Are there potential risks for tourists? International Journal of Safety and Security in Tourism and Hospitality, 1(2), 1-17.

Brüssow, H. (2020). The Novel Coronavirus-A snapshot of current knowledge. Microbial Biotechnology, 13, 607-612. https://doi.org/10.1111/1751-7915.13557.

Dodds, R., \& Butler, R. (2019). Overtourism: Issues, realities and solutions. De Gruyter Oldenbourg.

Fauci, A.S., Lane, H.C., \& Redfield, R.R. (2020). Covid-19 - Navigating the uncharted. The New England Journal of Medicine, 382(13), 1268-1269. https://doi.org/10.1056/NEJMe2002387

Fernandes, N. (2020). Economic effects of coronavirus outbreak (COVID-19) on the world economy, Available at: http://dx.doi.org/10.2139/ssrn.3557504

Freeman, R.E. (1984). Strategic management: A stakeholder approach. Boston: Pitman.

Fotiadis, A.K., \& Huan, T.C. (2014). Disaster, tourism. In J. Jafari \& H. Xiao (Eds.), Encyclopedia of Tourism. Cham: Springer International Publishing.

Gentile, I., \& Abenavoli, L. (2020). COVID-19: Perspectives on the potential novel global threat. Reviews on Recent Clinical Trials, 15(2), 1-3. https://doi.org/10.2174/1574887115999200228100745

Gössling, S., Scott, D., \& Hall, C.M. (2020). Pandemics, tourism and global change: A rapid assessment of COVID-19. Journal of Sustainable Tourism, 1-20. https://doi.org/10.1080/09669582.2020.1758708.

Grewal, A., Kataria, H., \& Dhawan, I. (2016). Literature search for research planning and identification of research problem. Indian Journal of Anaesthesia, 60(9), 635-639. https://doi.org/10.4103/0019-5049.190618

Huan, T.C., Beaman, J., \& Shelby, L. (2004). No-escape natural disaster: Mitigating impacts on tourism. Annals of Tourism Research, 31(2), 255-273. https://doi.org/10.1016/j.annals.2003.10.003

Jamal, T., \& Budke, C. (2020). Tourism in a world with pandemics: Local-global responsibility and action. Journal of Tourism Futures, 6(2), 181-188. https://doi.org/10.1108/JTF-02-2020-0014

Karim, W., Haque, A., Anis, Z., \& Ulfy, M.A. (2020). The movement control order (MCO) for COVID-19 crisis and its impact on tourism and hospitality sector in Malaysia. International Tourism and Hospitality Journal, 3(2), 1-07. https://doi.org/10.37227/ithj-2020-02-09

Korinth, B., \& Ranasinghe, R. (2020). COVID-19 pandemic`s impact on tourism in Poland in March 2020. GeoJournal of Tourism and Geosites, 31(3), 987990. https://doi.org/10.30892/gtg.31308-531

McKercher, B., \& Chon, K. (2004). The over-reaction to SARS and the collapse of Asian tourism. Annals of Tourism Research, 31(3), 716-719. https://doi.org/10.1016/j.annals.2003.11.002

Novelli, M., Gussing Burgess, L., Jones, A., \& Ritchie, B.W. (2018). No Ebola. Still doomed - The ebola- induced tourism crisis. Annals of Tourism Research, 70, 76-87. https://doi.org/10.1016/j.annals.2018.03.006

Orlik, T., Rush, J., Cousin, M., \& Hong, J. (2020). Coronavirus could cost the global economy \$2.7 trillion. Here's how, Bloomberg economics, NiGEM, OECD. https://www.bloomberg.com/graphics/2020-coronavirus-pandemic-global-economic-risk/.

Pastor, C.K.L. (2020). Sentiment analysis on synchronous online delivery of instruction due to extreme community quarantine in the Philippines caused by COVID-19 pandemic. Asian Journal of Multidisciplinary Studies, 3(1), 1-6.

Plog, S.C. (2001). Why destination areas rise and fall in popularity: An update of a Cornell quarterly classic. Cornell, Hotel and Restaurant Administration Quarterly, 42(3), 13-24. https://doi.org/10.1016/S0010-8804(01)81020-X

Seraphin, H., Sheeran, P., \& Pilato, M. (2018). Over-tourism and the fall of Venice as a destination. Journal of Destination Marketing \& Management, 9,374 376. https://doi.org/10.1016/j.jdmm.2018.01.011

Shang, W., Yang, Y., Rao, Y., \& Rao, X. (2020). The outbreak of SARS-CoV-2 pneumonia calls for viral vaccines. npj Vaccines, 5(1), 1-3. https://doi.org/10.1038/s41541-020-0170-0

Smith, E. (2008). Using secondary data in educational and social research. New York, NY.

Sönmez, S., Wiitala, J., \& Apostolopoulos, Y. (2019). How complex travel, tourism, and transportation networks influence infectious disease movement in a borderless world. In D. J. Timothy (Ed.), Handbook of Globalisation and Tourism, Edward Elgar Publishing Limited, UK. https://doi.org/10.4337/9781786431295.00015

Wahyuningtyas, N., Tanjung, A., Idris, I., \& Islam, M.N. (2020). Accelerating tourism development by community preparedness on disaster risk in Lombok, Indonesia. GeoJournal of Tourism and Geosites, 29(2), 545-553. https://doi.org/10.30892/gtg.29213-488

Wendt, J.A. (2019). Comparison of the impact of the Arab spring and terrorist attacks on the decline in tourism in Egypt and Tunisia (2010-2015). GeoJournal of Tourism and Geosites, 27(4), 1367-1376. https://doi.org/10.30892/gtg.27421-440

*** ABC News. (2020). Coronavirus is a public health emergency. World Health Organization declares. https://www.abc.net. au/news/2020-01-31/whocoronavirus-global-emergency/ 11916276

*** Databd.co (2020). COVID-19 \& tourism: A tragic end to the thriving industry?. https://databd.co/stories/covid-19-tourism-a-tragic-end-to-the-thrivingindustry-11643?fbclid=IwAR1RqrcuiR_GUCIzbm_NjwTloML6KxQbOd85aQ1ELZetMoUkKabHmV2t7HE

*** ILO (2020). COVID-19 and the world of work: Impact and policy responses. https://www.ilo.org/wcmsp5/groups/public/---dgreports/-dcomm/documents/briefingnote/wcms738753.pdf

*** UNWTO (2020a). World tourism barometer. 18(5), 1-36, Published by: UNWTO.

*** UNWTO (2020b). World tourism barometer. 18(2), Published by: UNWTO.

*** UNWTO (2020c). World tourism barometer. 18(1), Published by: UNWTO.

*** UNWTO (2020d). Impact assessment of the Covid-19 outbreak on international tourism. https://www.unwto.org/impact-assessment-of-the-covid-19outbreak-on-international-tourism.

*** UNWTO (2020e). International tourist arrivals could fall by 20-30\% in 2020. https://www.unwto.org/news/international-tourism-arrivals-could-fall-in-2020.

*** UNWTO (2020f). When do you expect tourism demand in your destination will start to recover? World Tourism Barometer. 18(2), 1-21.

Ying, T., Wang, K., Liu, X., Wen, J., \& Goh, E. (2020). Rethinking game consumption in tourism: a case of the 2019 novel coronavirus pneumonia outbreak in China. Tourism Recreation Research. https://doi.org/10.1080/02508281.2020.1743048

*** Worldometers (2020). Covid-19- Coronavirus pandemic. https://www.worldometers.info/coronavirus/.

*** World Bank. (2020a). Air transport, passengers carried. https://data.worldbank.org/indicator/is.air.psgr

*** World Bank. (2020b). International tourism, number of arrivals. https://data.worldbank. org/indicator/ST.INT.ARVL.

*** World Economic Forum. (2020). This is how coronavirus could affect the travel and tourism industry. https://www.weforum. org/agenda/2020/03/worldtravel-coronavirus-covid19-jobs-pandemic-tourism-aviation/.

*** WTTC (2020). WTTC now estimates over 100 million jobs losses in the travel \& tourism sector and alerts 620 countries to the Scale of the Crisis. https://wttc.org/NewsArticle/WTTC-now-estimates-over-100-million-jobs-losses-in-the-Travel-\&-Tourism-sector-and-alerts-G20-countries-to-the-scale-of-the-crisis. 